Lurian Journal. 2020. Vol. 1, No. 2. P. 58-70.

D0l 10.15826/Lurian.2020.1.2.5

УДК 159.955.000.93

\title{
Ways of Development of the Russian Methodology: Answers and Questions of the Psychology of Thinking
}

\author{
Diana B. Bogoyavlenskaya \\ Psychological Institute of Russian Academy of Education, \\ Moscow State Pedagogical University, \\ Moscow, Russia
}

\section{Пути развития отечественной методологии: ответы и вопросы психологии мышления}

\author{
Диана Б. Богоявленская \\ Психологический институт Российской академии образования, \\ Московский педагогический государственный университет, \\ Москва, Россия
}

Corresponding author. E-mail:mpo-120@mail.ru

\begin{abstract}
The article refers the formation and development of the Russian methodology in the frame of which the theory of thinking has been built. The exposition of the theory developed in the twenties-nineties of the 20th century becomes topical because of two factors.

The first factor of the demand from the intensively developing neuroscience. Various directions in this field aiming to studying thinking disorders, particularly in schizophrenia, are lacking theoretical concordance. That is why the specialists come to the conclusion on necessity of a common scientifically justified platform: the development of the theory of thinking. We would like to mention that the attention for an impaired function is typical for a physician, whereas for a psychologist the problem of revealing unusual strength of thinking is schizophrenia is significant. Solving this problem is important for the theory of thinking itself.

The second factor of the demand for designing the theory of thinking is the change of paradigm in the science and education during the nineties of the 20th century, which has stimulated the variety of theoretically unjustified approaches to interpretation of nature of thinking. That is why when reviewing the theory of thinking we consider the significant events which defined the vector of its development beginning with Rubinstein's article of 1922 The Principle of Creative Self-Activity (To the Philosophical Foundations of Modern Pedagogy), where methodological justification of the conception of subject is given. In 1930 he
\end{abstract}


formulates the principle of thinking as the "unity of consciousness and activity." At the same period Luria explains the positions which are in tune with the future cultural-historical methodology of Vygotsky. The research of thinking as a process is given in the Soviet psychology by the school of Rubinstein in the Fifties-Sixties and after his death in 1969. The works with description of meaning, sense and nature of the word became Luria's contribution in the analysis of the structure of thinking process when solving problems. We consider the common idea of solving problematic situations as the result of creative thinking to be its lowest stage, immature form, as in the frame of solving the given tasks, i. e. stimulus-projective model in which the whole psyche had been studied, it is impossible to come to analysis of the phenomenon of creativity. That succeeds only in designing a new method. In the course of the experiment, the Creative Field method allows revealing the ability of a person to develop the accepted ability by his initiative. The levels of cognition to be reached by the testee are described. They correspond to the level of displays of creativity or to its absence. This approach finds its theoretical basis in the cultural-historical psychology (Vygotsky). We have revealed the highest mature form of creativity as development of the activity by one's initiative which is the unit of analysis where, according to Vygotsky, "the meeting of affect and intellect occurs." The examples of children who have shown the highest level of creativity are described. Among them there is a nine-year boy with the diagnosis of schizophrenia, who spontaneously formulated very precise and capacious definition of creativity.

Keywords: thinking; theory; creativity; development of activity; unit of analysis

Аннотация. В статье рассматриваются основные этапы становления и развития отечественной методологии, в рамках которой создавалась теория мышления. В 20-80-е гг. $\mathrm{XX}$ в. теория мышления вновь стала актуальной в связи с запросом со стороны бурно развивающейся нейронауки. Множество разрабатываемых в ее рамках направлений по изучению нарушений мышления, в частности, при шизофрении не были теоретически согласованы. Поэтому специалисты приходят к выводу о необходимости разработки единой научно обоснованной теории мышления. Заметим: для медика естественно внимание к нарушениям функции, но для психолога значима также проблема раскрытия необычности мышления при шизофрении. Решение данной проблемы значимо и для самой теории мышления. В 90-е гг. интерес к построению теории мышления был связан со сменой парадигмы в науке и образовании, что породило множество теоретически не обоснованных подходов к интерпретации природы мышления. Поэтому, излагая теорию мышления, мы рассматриваем значимые события, определившие вектор ее развития, начиная с анализа статьи С. Л. Рубинштейна 1922 г. «Принцип творческой самодеятельности (К философским основам современной педагогики)», где дается методологическое раскрытие понятия субъекта. В 1930 г. ученый формулирует принцип познания как «единство сознания и деятельности». В тот же период А. Р. Лурия излагает позицию, созвучную будущей культурно-исторической методологии Л.С. Выготского. В 50-60-е гг. исследование мышления как процесса представлено в отечественной психологии школой Рубинштейна, работа продолжалась и после его смерти, до 1969 г. Исследования по описанию значения, смысла и природы слова 
стали вкладом А.Р. Лурия в анализ структуры мыслительного процесса при решении задач. Вопреки распространенному представлению о решении проблемных ситуаций как результате творческого мышления, мы рассматриваем этот процесс как низшую ступень, поскольку на основе «стимульно-реактивной» модели, в рамках которой изучалась вся психика человека, нельзя выйти на анализ феномена творчества. Нам удалось это сделать лишь в результате разработки нового метода. Метод «креативного поля» позволяет во время эксперимента выявить способность человека развивать деятельность по собственной инициативе и определить уровни познания, на которые выходит испытуемый, чтобы диагностировать у него отсутствие способности к творчеству или уровень ее проявления. Теоретическое обоснование данный подход находит в культурно-исторической психологии (Л.С. Выготский). Нами выделена высшая форма творчества как развития деятельности по собственной инициативе, выступающая единицей ее анализа. По словам Л. С. Выготского, в процессе творческой деятельности «происходит встреча аффекта с интеллектом». Мы приводим примеры того, как дети проявляют высший уровень творчества (так, 9-летний мальчик с диагнозом шизофрении спонтанно смог выйти на точное, емкое определение творчества).

Ключевые слова: мышление; теория; творчество; развитие деятельности; единиияа анализа

\section{Introduction}

Schizophrenia is one of the common mental diseases and it is also a topical problem of the psychology of creativity. Quite often the scientific hypotheses advancing the knowledge of their time are considered as the displays of geniality or - of schizophrenia: time will show.

The research of thinking disorders in schizophrenia has been carried out in medicine and psychophysiology in a wide range of directions. In the Cherednikova's book Modern Neuropsychological, Neurogenetic and Neuromathematic Conceptions of Thinking Disorders in Schizophrenia a brief review of foreign conceptions in these fields is introduced. Emphasizing the importance of ideas of complex multilevel system organization of neurobiological mechanisms of thinking disorders the author mentions the variety of theoretical views in the modern neuroscience and frequently observed lack of concordance of opinions in the sphere of research of thinking disorders (Cherednikova, 2011).

Contributing to the problem, this variety of conceptions along with their contradictions brings to the conclusion on the necessity of designing general psychological theory of thinking. Obviously, it is impossible to create the theories of thinking disorders without understanding the normal thinking.

It is even more difficult to answer the question about not the disorder of thinking but about the abnormal strength of generalization of thinking in schizophrenia. In this article we will try to mark our approach or, rather its vector, in putting this question. 


\section{The Russian Theory of Thinking}

\section{The Formation Period}

In 1922 Rubinstein's article The Principle of Creative Self-Activity (To the Philosophical Foundations of Modern Pedagogy) the concept of Subject is set as a significant vector: "In his actions, in the acts of his creative self-activity the subject is not only found and shows himself, he is created and defined by them. By what he makes can be defined what he is" (Rubinstein, 1922/1986, p. 105). Further on, in the Thirties Rubinstein (1922/1986) formulates on this foundation the basic principle of cognition as the "unity of consciousness and activity."

In tune with that, we read in an early Luria’s work (2003): "When studying real human psyche we should not isolate a person from the world where he lives, from the environment under the influence of which he is forming, from the historical moment during which his life passes" (p. 316). This effort to understand the structure of a mental function makes him the closest co-worker of Vygotsky, who explained how the evolution results build the psyche.

\section{Studying Thinking as a Process}

In 1950 Rubinstein starts lecturing for the group of psychologists in the philosophical faculty of the Moscow State University.

During the same year Luria is giving lectures in general psychology in the philosophical department of the same faculty. When making definition of the process of thinking, Luria mentions that human thinking, which is based on the object activity and means of language, not only organizes the person's perception and allows making a leap from sensual to rational, not only allows transferring a message using the means of language, coding the thought in the verbal expression, revealing its internal meaning but to be also a special form of productive activity. Luria emphasizes that thinking that leads to new conclusions is a theoretical activity because a thinking human is capable to reason and to solve logical problems not including the practical activity in this process. In absence of univocal algorithms, a man should find a way of solving a complex task himself. It characterises creative thinking. The way Luria analyzes further the process of solving is of crucial importance. He starts from the point:

The problem always sets an aim in the question. This question does not contain the answer itself. The aim is given in certain conditions and the subject solving the problem first of all should orientate himself in its condition; to mark out the most important things from its contents by comparing the included parts. Only such work representing the orientation basis of the intellectual action allows create the hypothesis of the way the solving has to follow, in other words, the strategy of solving, its general scheme (Luria, 2006, p. 312).

He indicates the factors included in problem solving which are the main conditions of the full-fledged intellectual activity. First of all, it is establishment of a logical relation 
between the word and the final question. He explains the meaning of this factor by dominating meaning of the question of the problem; without this "subordination to the question various associations and a choice from many possible alternatives can arise. That way the intellectual activity dissociates" (Luria, 2006, p. 312).

The second factor for retention of the intellectual activity is pre-orientation in the conditions of the problem. It provides the review of all elements of the condition and building a general scheme of problem solving.

The consecutive realization of the principle of cognition as the "unity of consciousness and activity" leads Rubinstein to the necessity of studying thinking not as the activity considering its motives, orientation, aims, but as a process as well. It is realized in the Fifties. After the cycle of the empirical research of thinking by the members of the school in 1959 he gives the exact wording:

The initial in thinking is the synthetic act - comparison the conditions and demands of the problem. The analysis is carried out in the frame of this comparison and by means of it... The transfer from one act of the analysis to the next one is defined in each case by the correlation of the result received by the analysis in the previous stage and the demands of the problem remaining unfulfilled. The initial determination of the process by the comparison of the conditions and demands of the task representing itself every time in new forms remains (emphasis added) during the whole process (Rubinstein, 1946, p. 97).

It should be mentioned that the doctrine of thinking as a process is the final stage of development of his theory, and I become his last student. Having known that I, the student of the philosophical department, am allowed to study at both departments at the same time, he said decidedly: "In this case we have to reveal the mechanism of insight." That is why my research started in the models of creative thinking - the brainteasers.

The first fact that drawn our attention in the course of the experiment was learning the conditions by a subject by using intensive verbal activity (several recitations of the conditions). After verbalization we have observed the transfer of the conditions to the object (subjective) code that provided the opportunity of transformation, addition and interpretation of the information coming as the problem, according to the information being kept in memory. That way the restoration of the object as the real contents of the problem occurs. That subjective vision of the conditions of the problem situation represents the image of the problem situation.

The real mechanism of this process is given by Luria in his description of the function of word as "reduplication of the world" by its object association, by generalization defining the meaning of the object and its meaning in presence of alternatives (Luria, 2006, p. 243).

But the figurative representation of the situation is just the first stage of mastering the conditions of the problem. It does not yet correspond to those conditions in a strict sense. Actually, the conditions of the problem are isolated in the process of this comparison of the figurative representation of the situation and the conditions of the problem. This moment seems to be extremely important as it becomes obvious that the demand 
defines the aspect, according to which the relevant sides of the objects are singled out in the initial material (the image of the problem situation). When using the well-known Helm's problem in our experiments, the demand to calculate the way defines the corresponding conditions: speed, distance, vectors of motion.

According to Rubinstein, the basis for comparison of the data can be the united system of concepts established in the process of correlation of the conditions and demand. Discretion behind this united conceptual system a certain non-linguistic representation (different from the expression in the natural language) of the conditions of the problem in the united field defines its heuristic value. This representation is being reached by abstracting from the irrelevant sides of objects in the problematic situation: due to this the conditions become heterogeneous and, as a consequence, comparable. The heterogeneity of the conditions allows leaving behind their qualitative contents and, in its turn, to come to the character representation of the conditions of the problem: "I see how beautiful bicyclists push pedals but then see them as line bars." The cyclists and the fly are represented as the line bars because now only the fact that they are moving bodies is important. The transfer to language of signs allows building the system of their relations in given problematic situation - its model (in the terms of gestalt-psychology the gestalt closure occurs). Alongside with that, the built-up system of relations is not a reflecting structure only, but the generating one as well. From it as from the result of the analysis of the problematic situation the hypothesis, the principle of solving is being read. The further analysis of this fact has led to the conclusion that the instantaneity of a guess is connected with the generating functions of the visual structure, named by us later the conceptual model of the problematic situation. It is really the viewing thought - by Goethe's expression. It is its first and the most important, heuristic function (Rubinstein, 1958).

It explains the idea guesstimated by Rubinstein already in the 1946 when he wrote about "special schemes that seem to anticipate verbally yet not unfold system of thoughts" (Rubinstein, 1946, p. 348).

The introduced aspect of analysis of thinking (comparing with its previous description in Rubinstein's school) indicates the character of language which has a strict functional meaning and is defined by the contents of the stage of thinking process. The described process allows solving another profound problem of our psyche: the correlation of its languages. The discretion in the K-model (conception model) the hypothesis of way of solving: the discretion as understanding, i.e. verbalizatiotin (the internal speech). It is finely formulated by Hunt as the "sensed sense" (Hunt, 2004, p. 235). Considering figurativespatial structure outside thinking has been criticized by Wecker (1998). The Arnheim's term visual thinking is also oriented against the rapture of languages realizing thinking. This unity of the languages of thinking Hunt explains by the role of intermodal translation, realized by the neocortex in humans (Hunt, 2004, p. 23). This phenomenon has been fixed by Heidegger as well, when he said that the hidden unity of vision and hearing defines the essence of thinking (Heidegger, 1991). It is important to consider it if a "patient" has impairment in interhemispheric coordination. 
The most topical idea is Rubinstein's analysis is the middle link of determination of thinking process: "The initial determination of the process by the correlation of the conditions and demands of the problem is being kept during the whole process coming out every time in new forms" (Rubinstein, 1959, p. 97). The expression coming out in new forms means reformulating the task connected with arising the main contradiction and its analysis in another, corresponding to its nature, system of relations. The transfer to it (the new system of relation) is called by Rubinstein the "basic nerve" (Ibid.) of the thinking process as it leads to solving the problem. It can be seen clearly in solving of the Dunker's problem: to build three equilateral triangles of six matches. The side is equal to the match. Even the graduates of the Moscow State University could not solve it for hours! The emotional burst is needed to give up the repetition of unsuccessful efforts and to make think!

"The problem cannot be solved as for four equilateral triangles twelve matches are needed. Bur we have six only. It too little, and every side should be common. And how is it possible?" Finally, the main contradiction comes clear and the analysis of it is transferring to another system of relations - geometry. How a side can be common?

If a persistent interest to the problem, meaning the presence of a dominant in the attention field, is kept at this stage, the appearance of an object of not a plane form to the field of view of the subject leads to the insight: the instant understanding of the way of solving problem in space (Bogoyavlenskaya, 2017c). If this speeding up of solving process does not occur, then in the end it becomes clear that a line in the plane is their common line. The problem is solved in space.

The fact of solving the problem by transfer of analysis into system of relations is empirically repeated and becomes a central condition in the system of revealing creativity in Guilford's theory (Guilford, 1965). The defect of such approach in the behaviorism paradigm is the fact that the choice of decisive system of relations is being reached not by a previous analysis of the problem, but by a width of the range of associations, including random coincidence.

\section{On the Nature of Creativity}

\section{The Ways of Realization of the Russian Methodology}

For understanding the conclusions of the research of character of thinking process determination it is important to make clear that it was carrying out by Luria and Rubinstein in solving problematic situations, i.e. in the frame of dominating stimulus-reaction model of studying the whole psyche. According to this model as soon as the demand of the problem is fulfilled the initial determination of the thinking process ceases to be. Arguing that "thinking initiates from the problem situation" Rubinstein emphasizes that "having the beginning it has the end as well" (Rubinstein, 1946, p. 235). But the revealed determination of thinking process has a relatively particular character covering the process of solving problematic situations, but not the cognition in general. In the situation of passion for a certain activity the activity can develop by subject's initiative. And it is here 
where we face the phenomena of "creative self-activity" and "spontaneous discoveries." Obviously, Rubinstein understood the significance of personality as the internal conditions of determination of thinking (Rubinstein, 1959, p. 116, 125). However, in the period of Fifties-Sixties this position was not realized operationally.

Designed only in 1969, the Creative Field method is nowadays the only technique built up not in the frame of the model stimulus - reaction. Its advantage is modelling the opportunity of the research activity of a person in real time conditions in the frame of the laboratory experiment. This method has been built up as a system of the problems of the same type. That provides two-level model of activity. The first, shallow level concerns solving certain problems allowing estimation of the intellect level of a person using all the parameters of educability. The second one is not obvious for a testee. The activity of revealing hidden regularities of the system of problems, the discovery of which is not needed to solve them, allows fixing the process of activity development by initiative of the testee (Bogoyavlenskaya, 2017b, 2019; Bogoyavlenskaya D. B., \& Bogoyavlenskaya M.E., 2018). But this "selmovement of activity" cannot be explained by mere qualities of intellect. According to Rubinstein (1922/1986), the realization of the attitude of a person to the world in the activity allows understanding the logic of the process.

In the frame of this article where we do not consider the mechanisms of thinking disorders but the opposition of them, the highest achievements in the field of creativity, some methodological principles based on the Vygotsky's theory are important. Vygotsky is the first one who has indicated that all sciences are developed two ways. The direct way is based on empirically discovered characteristics. The opposite way comes out of the knowledge of the highest form and demands theoretical justification of the highest form of the phenomenon to be studied. It is on the "opposite" way the realization of Vygotsky's (2016) principle becomes possible: "Psychology, willing to study complex psychic phenomena should change the methods of reducing to elements by the method of analysis reducing to units" (p. 8). The ability of developing activity by one's initiative answers the methodological demands of the "unit of analysis" of creativity, where according to Vygotsky "the meeting of affect and intellect" occurs and abstraction of one of the sides is impossible as it is "indecomposable" (Ibid.).

Finally, we can talk about mechanism of creativity not as of the mystical creating "of nothing" - a special creative ability, but as development of further reconsidering the activity to which we are committed.

The total number of participants of the experiments including the Creative Field method is more than 10000 persons in the age from five to eighty years, and that includes a longitudinal research lasting more than 50 years.

\section{Typology of Creativity}

The Creative Field method allows tracing how the exploratory search develops or does not develop in the frame of the activity a person masters a new. The direction of the analysis can be traced in three levels of cognition and it allows building its typology. 
We consider the activity of a person including the level of the highest skilfulness, as belonging to the first level if is stimulated from outside. The motivation of a wide range can influence successfulness of work. It is the motive of achievements, level of aspirations and everything that provides self-realisation of a person. The process of thinking on this level stops as the problem is solved. According to Hegel, it is solving on a single level. We name it the stimulus-productive level. Unfortunately, four fifths of the sample belong to it.

The activity developed by the initiative of a person belongs to the second - the heuristic level. Motivation at this level is limited by domination of the cognitive need in the structure of subject of activity. The motives of achievement are in conflict with the need of cognition. This is the level of art and discovering laws, which Rubinstein described as blasting the layers of the matter. Even great scientists survive the feeling of delight, when they discover a new regularity in our simple experiment: "It is rather plain, but it's mine..." This is the process of cognition at the level of the special. In the philosophical literature this is the way of characterizing the talent. Less than twenty per cent of the sample belong to this level.

The third level, the creative one (we use the Latin word in order to distinguish it from the heuristic and stimulus-productive levels), is characterized not by discovering new regularities but their theoretical proving as well. This is the level of building theories and setting new problems. The process of cognition occurs on the level of the whole. Such process provides the cognition of the essence of object. But having cognized the essence of a phenomenon it is possible to foresee qualitative leaps in its development and that defines the prognostic abilities of a subject. It is this ability that, according to philosophers, characterizes the genius, who can foresee centuries ahead (Bogoyavlenskaya, 2019; Bogoyavlenskaya D. B., \& Bogoyavlenskaya M.E., 2018). We would like to remind, that it is the presence of a theoretical thought correctly reflecting reality that is connected to forming Noosphere, according to Vernadsky.

\section{Nature of the Process of Creation}

In this part of the article the most typical displays of the highest level of creativity are described. Three first protocols demonstrate the manifestations of creativity. The fourth protocol shows why a patient with schizophrenia can not learn in a common school. The description of behaviour of a nine-year boy with the diagnosis schizophrenia puts an important question which science can not answer yet.

Protocol No. 1. "The second math-school," 10th form, 1970. A boy finds the way of solving at the first problem and solves the second one very quickly. On the third problem the time of solving is one-two minutes longer. As if making an excuse, he explains: "I have proved the theorem." I am stricken by the speed of reaching the third level, so I thank the boy and tell him that the experiment is over. He is surprised and shows me blank forms. I explain that they are meant for a larger number of problems. The boy asks what so many problems are for. "We are taught this way: if you see regularity, then prove it." Comparing with usual concern of the boys, who is faster, this lack of self-affirmation looked very promising. 
After finishing the post-graduate study, he wrote a book, compared by its significance with a chapter from the famous Landau series. In the beginning of 2000s, he was elected in the Russian Academy of Science (RAS). Two years ago, being a director of a leading institution of the RAS he came to me for the next experiment (Bogoyavlenskaya, 2017a).

Protocol No. 2. School 91. 2nd form. On the adapted to the abilities of the age chart imitating a structure of the circus, a child should find a place for a cat catching a performing mouse that run from the stage. The child finds this place quickly and after presenting him a range of similar problems comes to generalization and explains how the cat's place should change depending on the mouse's position. The experiment continues and suddenly the boy's eyes flash of excitement and slightly gasping for breath because of agitation (I understand that he came to the proof of the revealed regularity) he says: "Such a clever cat!" It is not him, who is clever - it is the cat. That says for the fact, that domination of the need for understanding saves his personality, his moral sphere from deformation and searching different ways of self-affirmation.

Protocol No. 3. School 57. The experiment with a boy from a 10th form has passed at ease. He is polite and restrained as a grown-up. Sequentially moving in the analysis of the material the boy steadily reaches the highest creative level. It was pleasant to chat with him after the experiment. We have discussed the forthcoming Olympiad in Australia as he had been prepared for it. I was delayed in the classroom packing the experimental materials and when I left the room, I heard his voice from the open door of the staff room. He asked to change the date of his duty in the class as he was not going to be in Moscow due to his trip to Australia. I remember that joy and feeling of pride for that good boy. I understood why his classmates talked of him with delight: I also experienced that feeling. Those children do not need to be "best of all." They need to think and to understand.

On this favourable background the sharper is the feeling of regret for the children whose achievements are subject of rapture, but then a tragedy follows.

On the request of the vice-president of the Russian Academy Science I was asked to sort out the problems of a gifted child. In the beginning of the experiment, before starting the work he mentions that two different forms: the square of the chess-board and lined circle, represent the same figure. Nobody, even academicians have not seen it. At first it takes my breath away, but after that I have got lump in my throat. What should I say to his mum? His tone of addressing to me demonstrates social inadequacy. In combination with such strength of the generalization the diagnosis is clear to me. I visit his school to understand why he can not learn there. Instead of the second form he is in the fourth one. Explaining the types of number, the teacher says that there are many stars in the sky and there are many students in the class. Vanya raises his hand. "What's the matter, Vanya?" - asks the teacher. "Mariya Ivanovna, your example is incorrect. The number of stars in the sky is infinite, but the number of students is finite." The teacher blushers, she is close to tears; stammering she continues the lesson. Passing Vanya during the break everybody pushes him. When he leaves the classroom, I follow him and it is the right time. 


\section{Observation}

In 1986 I visited the "Socrat" school as a member of a large committee. We were present at the lesson of physics, conducted by two teachers with the PhD Degree in physics and math, who were teaching the students of nine years old. Due to their enthusiasm for physics they studied the curriculum of the eighth form. But the members of the committee were surprised not by the volume, but the deepness of knowledge of the children. Their reasoning was so professional that sometimes we forgot that they were children, not adults. When the lesson was over everybody was speechless. Finally, the inspector of the Ministry of Education addressed to a boy of a small height: "Oleg, tell me please which creative tasks have you performed in math today?" The answer: "None" perplexed everybody. "And what about physics?" - continued she questioning. She got the same answer: "None." Seeing everybody's bewilderment, Oleg with explained them a childish directness that the creative tasks in math, physics and biology could not exist. The distrust on our faces made him to explain that the creative tasks existed in the lessons of Russian only. There was even a header the "Creative work" on a sheet of paper.

The animation in the class was treated by the boy adequately. "You should not mix the level of performance with the name - the creative work" - he argued passionately. Wishing to prove his case he asked for a minute for reflexion. A minute later he pronounced proudly: "Everything is correct. The creative work is a set expression." At that moment we remembered that out of mouth of babes comes truth. The emotional shock we experienced at that moment could not go away quickly. Probably, it is getting stronger as time passes. The boy's words have caught the definition of creativity fixed in practice, but having become commonplace and loosen its original meaning.

\section{Conclusion}

Ex ore parvulorum ehr veritas (Out of mouths of babes comes truth) - Latin expression.

In 1997 as a prologue to the book The Main Modern Conception of Creativity and Giftedness prepared by me with the grant of the President Programme "The Children of Russia” I included the description of above-mentioned meeting with Oleg (p. 5). I did it because in passing along with highlighting inadequacy of naming the creative work something without guarantee of creativity manifestations, he gave a capacious and precise definition of creativity. "You should not mix the level of performance with the name the creative work," he reveals the essence of what is creativity. It is amazing how the boy of nine years not specially reflecting on this problem, reflexes involuntary that when solving physical and mathematical problems his thought does not stop at the answer, but often goes further. The question of the creative works in mathematics actualizes the process of movement by the levels of cognition. Perhaps, I understand Oleg best of all as the conception of creativity as the ability for developing activity (the thinking activity) by one's initiative I consider is equal to his thought. There is no creativity except the spontaneous movement of one's thought. 
After the above-mentioned meeting with Oleg I received the permission for diagnostics in the "Socrat" school a year later. According to my calculations, Oleg should have been finishing the 10th form at that moment. Having come to school I learned that Oleg was not visiting school and due to acute condition of his disease he could not learn anymore. This loss made the feeling of responsibility for the sick children and unfairness of observing their abilities from outside sharper. That is why not to sound unsubstantiated, I would like to draw the attention to the fact the what has been reached by psychology of thinking and creativity in the advanced Russian methodology for a hundred years, has been formulated by a nine-year child with schizophrenia. What is its mechanism and why its development leads to the death of the child? Is the result of a powerful inflow of neurons as by the dominant, but unfinished mielinogenesis of the brain leads to its death? Can it be prevented? The answer to this question is important for defining the ways of development of psychology of thinking.

\section{References}

Bogoyavlenskaya, D. B. (2017a). Longitudinal study of the dynamics of giftedness. Russian Psychological Journal, 15(S2/1), 5-18.

Bogoyavlenskaya, D. B. (2017b). Once more about the concepts of creativity and giftedness: Methodological approach. In L. M. Larionova, A. I. Savenkov (Eds.), Psychology of giftedness and creativity (pp. 21-36). Moscow; StPetersburg: Nestor-Istoria. [In Russian]

Bogoyavlenskaya, D. B. (2017c). Poincaré Phenomenon - Modern Interpretation. Issues of Philosophy, 12, 103-109. [In Russian]

Bogoyavlenskaya, D. B. (2019). Philosophical fundamentals of the theory of giftedness. CulturalHistorical Psychology, 15(2), 14-21. https://doi.org/10.17759/chp.2019150202 [In Russian]

Bogoyavlenskaya, D. B., \& Bogoyavlenskaya, M. E. (2018). Giftedness: Nature and diagnostics. Moscow: CNPRO. [In Russian]

Cherednikova, T. V. (2011). Modern neuropsychological, neurogenetic and neuromathematical concepts of schizophrenic thought disorders (review). Psychological Research, 1(15). Retrieved from http://psystudy.ru. [In Russian]

Guilford, D. (1965). Three sides of intellect. In: A. M. Matyushkin (Ed.), The psychology of thinking (pp. 433-456). Moscow: Progress. [In Russian]

Heidegger, M. (1991). The principles of mind. Moscow: Science. [In Russian]

Hunt, H. T. (2004). On the nature of consciousness. Moscow: AST. [In Russian]

Luria, A. R. (2003). Principles of real psychology (On some trends in modern psychology). In J. M. Glozman, D. A. Leontiev, E. G. Radkovskaya (Eds.), Psychological legacy: Selected works in general psychology (pp. 295-383). Moscow: Smysl, 2003. [In Russian]

Luria, A. R. (2006). Lectures in general psychology. StPetersburg: Peter. [In Russian]

Rubinstein, S. L. (1946). Foundations of general psychology. Moscow: Science. [In Russian]

Rubinstein, S. L. (1958). On thinking and the ways of its research. Moscow: The Academy of Sciences of the USSR Press. [In Russian] 
Rubinstein, S. L. (1959). Principles and ways of development of psychology. Moscow: The Academy of Sciences of the USSR Press. [In Russian]

Rubinstein, S. L. (1986). Principle of creative self-activity (To the philosophical foundations of modern pedagogy). Issues of Psychology, 4, 101-108. [In Russian] (Original work published 1922)

Vygotsky, L. S. (2016). Thinking and speech. Moscow: National Education. [In Russian]

Wecker, L. M. (1998). Psyche and reality: A unified theory of mental processes. Moscow: Smysl. [In Russian]

Original manuscript received May 05, 2020

Revised manuscript accepted July 14, 2020

First published online November 13, 2020

To cite this article: Bogoyavlenskaya, D. B. (2020). Ways of development of the Russian methodology: Answers and questions of the psychology of thinking. Lurian Journal, 1(2), 58-70. doi: 10.15826/Lurian.2020.1.2.5 